\title{
Ex Post Evaluation of Thirty Years of Compact Urban Development in the Netherlands
}

\author{
Karst T. Geurs and Bert van Wee ${ }^{a}$ \\ Published in Urban Studies 41, No. 1, 139-160.
}

\begin{abstract}
Despite the wide array of academic research, the impacts of compact urban development are not very well understood. What is lacking are, firstly, the insights into how a region or country would have appeared under policy regimes other than those realised and, secondly, a broad evaluation of relevant land-use, transport, accessibility and related societal and ecological impacts. Here, we report on an initial attempt to establish a methodology and evaluation framework for analysing the effectiveness of Dutch compact urbanisation policies implemented between 1970 and 2000. Our conclusion is that without compact urban development policies, urban sprawl in the Netherlands would have likely been greater, car use would have been higher at the cost of alternative modes, emission and noise levels in residential and natural environments, and the fragmentation of wildlife habitats would have been higher.
\end{abstract}

\section{Introduction}

The last few decades have seen an increasing interest in how urban form - e.g. a city's densities, size, configurations and distribution of open space - can contribute to sustainable development. In Europe, the USA and Australia there was strong advocacy for the 'compact city' concept, essentially high-density, mixed-use cities, with clear (i.e. non-sprawling) boundaries (Jenks et al., 1996; Williams et al., 2000). The compact city and many of the urban design and planning movements in Europe and the United States, such as 'New Urbanism', 'Sustainable Communities' and 'Smart Growth', aimed to promote more sustainable patterns of travel, reduce car travel and related energy use and air pollution (e.g. see ECOTEC, 1993, Ryan \& McNally, 1995; Banister, 1997; Williams et al., 2000, Stead \& Marshall, 2001). However, claims of the contribution of compact urbanisation to sustainable development have been contested in the literature ever since. In particular, academic research on the links between compact urbanisation and travel behaviour is not conclusive, with results differing considerably depending on the methodology used, data limitations and spatio-temporal settings (see Handy, 1996; Anderson et al., 1996; Wegener \& Fürst, 1999; Stead \& Marshall, 2001; Meurs \& Van Wee, 2004; for elaborate reviews.). In this article we extend the debate on compact urban development, identifying two main gaps in the knowledge on the effects of compact urban development. Firstly, existing empirical and model simulations may have

\footnotetext{
${ }^{a}$ Karst Geurs is from the Netherlands Environmental Assessment Agency, P.O. Box 303, 3720 AH Bilthoven, The Netherlands. Fax: 3130 2744417. Email: karst.geurs@ mnp.nl. and Bert van Wee from the Delft University of Technology, Delft, The Netherlands. Fax: 31152782719. Email: g.p.vanwee@tbm.tudelft.nl
} 
underestimated the impacts of compact urbanisation on transport, because landuse patterns that encourage car travel beforehand are not considered, e.g. scenarios with urbanisation patterns similar to those in many parts of the United States - very low housing densities in suburbs far away from public transport and city centres with shops and services for non-daily needs. Thus, what is essentially lacking is insight into how a region or county would really have looked like under other policies than those actually implemented.

A second gap in our knowledge is that most research focuses on travel behaviour indicators only, although the research context is often based on environmental impacts of transport. Where environmental indicators are used, energy use and/or emission levels (virtually without exception) are the only ones. However, for a full understanding of the impacts of compact urban development, a broader appraisal framework is necessary, in which land use, travel behaviour and accessibility impacts are reflected, along with related societal and ecological impacts. In academic research, little attention has been paid to environmental impacts such as local air pollution, noise and habitat fragmentation of nature conservation areas (Van der Waals, 2000); there are even more gaps in our knowledge on social and economic impacts.

A study applying a broad evaluation framework about how an area would have appeared under other policy regimes than the one realised, has, to our knowledge, never been carried out. In this paper we present such a study for the Netherlands, which describes an initial attempt to establish a methodology and evaluation framework for analysing the effectiveness of Dutch national spatial planning policies implemented between 1970 and 2000. The study consisted of three phases. In the first phase, a dynamic GIS-based, land-use transport interaction model was developed and applied in a study simulating the real-world, land-use and transport developments in the Netherlands on a yearly basis from 1970 to 2000. The second phase focused on the development of alternative landuse scenarios for Netherlands for the same period. In the third, and final phase, the impacts of the reference and alternative land-use scenarios were computed and evaluated using a range of land-use, transport, accessibility and related social and ecological indicators.

A considerable part of the literature on the impacts of compact urbanisation described in this paper refers to the Dutch situation. For this reason, section 2 starts with a short description of Dutch national spatial planning policies. Section 3 briefly overviews the literature on the impacts of compact urbanisation on travel behaviour, and societal and ecological indicators. Section 4 describes the modelling and appraisal methodology, while section 5 presents the results and section 6 the conclusions.

\section{Compact Urbanisation Policies in the Netherlands}

Dutch spatial planning, especially at the national level, has been characterised by a great number of spatial policy concepts, even though the basic principles 
continued to be the same (Hajer \& Zonneveld, 2000). For 30 years national spatial planning policies in the Netherlands were aimed at implementing compact urbanisation in various forms. Most efforts were directed mainly to the Randstad, a distinctive polynucleated pattern of urban centres in the western part of the Netherlands (including the major cities of Amsterdam, Rotterdam, The Hague and Utrecht and a substantial number of smaller cities). The urban centres are arranged roughly in the form of a horseshoe, encircling the "Green Heart", a rural area where a few small towns and numerous villages are located (Figure 1). Before going on we will go back to the late 1960s for a short overview of Dutch national spatial planning policies.

The first powerful stand against the suburban sprawl was taken in the Second Report on Physical Planning (Ministry of Housing and Physical Planning, 1966). The main rationale then concerned efficient land use (land being considered an irreplaceable asset), and funding of services and infrastructure and to preserve the Green Heart. The proposed alternative was to channel suburbanisation into "concentrated deconcentration", i.e. accommodate new urban growth outside existing urban areas in a number of designated overspill centres. This policy was seen as a feasible compromise between concentration and lowdensity dispersal of urban activities. Compact urban development has remained the cornerstone of Dutch physical or spatial planning ever since.

The policy of concentrated deconcentration was continued in the Third National Report on Physical Planning (Ministry of Housing, Physical Planning and the Environment, 1977), but more strictly regulated and controlled. The locations for new towns were now designated by national government, since the spatial planning process of provincial and local authorities had been insufficiently controlled in the preceding period (Van Straten et al., 1996). The Third Report, written a few years after the first oil crisis and the publication of Meadow's Limits to Growth (Meadows et al., 1972), added reduction of (the need for) car travel, while promoting non-motorised and public transport as a new rationale for compact urban development. The aim here was to reduce energy use and environmental pollution, along with the demand for road infrastructure.

During the 1980s, the concept of concentrated deconcentration changed to the "compact city" policy, due mainly to the decline of inner cities, partly blamed on the policy of concentrated deconcentration (Dieleman et al., 1999). Via the Fourth Report on Physical Planning Extra (Ministry of Housing, Physical Planning and the Environment, 1991), the government tried to guide new urban (re)development to locations within the existing urban areas ("Brownfield" locations) and new "Greenfield" locations near existing cities ("VINEX" locations). These were found in the Randstad and designated by the national government. Between 1995 and 2005, a total of almost 460,000 dwellings are to be built on the VINEX locations, of which about half will be built on Greenfield locations in the Randstad. Here, housing density is relatively high, and includes places of work and services. Heavy investments in urban renewal were also initiated to improve the quality of the housing stock. At the same time, restrictive 
planning measures protected the Green Heart from major urban development. The National Ecological Network, a network of nature conservation areas enjoying special protection from land-use developments, was set up. The main arguments for compact urban growth were the same as in the 1970s, but introduced a halt to inner-city decline as a new argument. The Fourth Report and Second Transport Structure Plan (Ministry of Transport, Public Works and Water Management, 1990) set a target to reduce the projected growth in car traffic between 1986 and 2010 from $70 \%$ to $35 \%$, which was to be met with spatial planning and transport policy measures. For example, concentrating housing and employment around public transport nodes would reduce the volume of peak-hour commuting traffic in major conurbations by 5-10\% (Ministry of Transport, Public Works and Water Management, 1990).

Dieleman et al. (1999) conclude that the implementation of compact urbanisation policies was largely successful. The new towns from the Third Report were developed as intended, certainly as far as housing is concerned, and in the 1990s the housing stock and number of inhabitants in the large cities started to grow again after a decade of serious decline. Furthermore, the Fourth Report's Brownfield and Greenfield (VINEX) locations were either already built or in development as planned, although the realisation of some Greenfield locations has been delayed (Spaans \& Trip, 2003). However, in recent years, there has no longer seemed to be a broad consensus of compact urbanisation as the cornerstone of spatial planning. During the course of implementing the concept of compact city development in the late 1990s, a heated debate on the merits, feasibility and costs arose and spread throughout administrative and policy circles in the Netherlands (Dieleman et al., 1999). Two important arguments were put forward. Firstly, the impact of urban form on car travel was a topic of discussion, both in the area of policy-making and under researchers. In policy-making, for example, the Netherlands VROM Council, an advisory board for the present Ministry of Housing, Spatial Planning and the Environment stated that influencing land-use patterns was considered ineffective in reducing national levels of car use and should not be further pursued (VROM Council, 1999). The researcher-related discussion is further explained in section 2.

Secondly, economic arguments were also added to the rationale of landuse planning. In the late 1990s several publications called for a relaxation of the strong emphasis on compact urban form to facilitate demands for housing and employment and to promote local and regional economic growth. This is, for example, expressed in a publication from the Ministry of Economic Affairs (Ministry of Economic Affairs, 1999). The discussions are reflected in the Draft Fifth National Policy Document on Spatial Planning (Ministry of Housing, Spatial Planning and the Environment, 2004) with a mixed perspective on compact urbanisation. Compact urban development would be replaced by a "network city" as a planning concept, and supervision on local authorities would be reduced (decentralisation). 
Furthermore, policy targets for reducing car travel would be abolished. However, restrictive land-use zoning was to preserve natural environments, open agricultural areas (the Green Heart) and other important landscapes. The policy of compact Greenfield housing locations would continue for the 2005 - 2010 period (to realise 226,000 dwellings), although with lower housing densities and more decentralised infrastructure funding (Spaans \& Trip, 2003).

\section{The Impacts of Compact Urbanisation: Dutch evidence}

\subsection{Empirical research on land use and transport linkages}

There is a wide array of literature on relations between land-use patterns and travel behaviour, but the results are not conclusive. Some researchers have concluded that urban form is a prime determinant of travel patterns and transport energy consumption and pollution can be substantially reduced by promoting compact urban development (e.g. Newman \& Kenworthy, 1989; ECOTEC, 1993; Kockelman, 1997; Newman \& Kenworthy, 1999; Williams et al., 2000) where others challenge this conventional wisdom (e.g. Breheny, 1995; Bagley \& Mokhtarian, 2002; Cervero, 2004; Headicar, 2004). In this section we will go into the literature briefly, focusing on literature where the Netherlands, part or whole, is the study area. Several authors have presented comprehensive reviews of international studies; see, for example, Anderson et al. (1996), Handy (1996), Wegener \& Fürst (1999), Badoe \& Miller (2000) and Stead \& Marshall (2001). Furthermore, contributions in the special issue of the European Journal of Transport Infrastructure Research $(2,2003)$ reviewed empirical evidence from the United States (Cervero, 2004), the UK (Headicar, 2004), the Netherlands (Van Wee \& Maat, 2004) and other European countries recently.

Academic research has paid considerable attention to travel behaviour impacts of urban design features, such as density, mixed neighbourhoods (diversity) and street lay-outs (design). Several studies confirm urban density, mixed land use, and design as variables having an impact on mobility, although links are weak (Cervero, 2004; Neass, 2004). As in many other countries, the number of empirical studies related to urbanisation in the Netherlands has been limited. This is remarkable since the Dutch government, more than governments in most other countries, has been seeking to influence travel behaviour through land-use policies. The most recent empirical studies are described here. Meurs \& Haaier (2001) carried out research into the impact of land use at the neighbourhood level and found that about $30 \%$ of the variation in the number of trips were explained by a wide variety of spatial factors, including density, characteristics of houses and street patterns, and the availability of facilities in the neighbourhoods. The study controlled for personal variables and location of the neighbourhood on an aggregate level. Hilbers et al. (1999) analysed travel behaviour of residents occupying a different type of VINEX location in the Netherlands and concluded from this analysis that different types of residential 
areas showed significant differences in travel behaviour, while controlling for socio-economic variables. In other words, car use of inhabitants from Brownfield locations, built within existing city or towns, is about one-third below the level of car use of inhabitants from VINEX Greenfield locations, built at the edges of existing towns. However, differences in travel behaviour between several types of Greenfield locations were rather small. Several researchers have analysed the impact of the residential area on travel behaviour using data from the Dutch National Travel Survey. Dieleman et al. (2002) analysed relationships between the type of residential environment (large cities, new towns, medium-sized towns, suburb/rural environments) and travel behaviour using multivariate models. They concluded characteristics of residential environments to be of equal importance as personal characteristics for mode choice and distance travelled. The combination of density, diversity and the supply of good public transport are shown to reduce car use in large and medium-sized cities in the Randstad area. In contrast, Schwanen (2003) concluded the influence of urban structure on commute behaviour to be relatively small; only $3 \%$ of the variation in commuter time and distance can be explained by the spatial context, when controlling for individual and household characteristics. This contrasting result may be due to the different research methods used; the study from Schwanen is one of the few using multilevel regression models. The only other example of a multi-level regression analysis examining the impact of land-use patterns on travel behaviour in the Netherlands is from Snellen (2001). She found hardly any evidence of the impact of land-use on travel behaviour at the local level, not even for densities.

In the Netherlands (as in most countries) more research has been carried out on the travel behaviour impacts of residential areas than impacts of work place (see for an overview Van Wee and Maat, 2004). The results of empirical studies focusing on work places seem less diffuse; all studies conclude that the location of work place matters: the share of public transport in commuting near public transport nodes (mainly: railway stations) is (much) higher than for locations near motorways, far away from public transport.

\subsection{Model simulation studies on land use and transport linkages}

In contrast to the few empirical studies related to urbanisation and travel behaviour, the number of scenario studies conducted on the whole of the Netherlands, or a large part of it, has been relatively high. Several model simulation studies in the Netherlands have been conducted to forecast travel behaviour impacts of future urbanisation concepts; see for review Van Wee \& Van der Hoorn (2001). Without exception, Dutch model studies have shown that land use can have a relatively strong impact on travel behaviour, with differences in car use as high as $20 \%$ or even more, of the travel to, from and within the areas where locations vary geographically (Van Wee \& Van der Hoorn, 2001). It is important to note that the absolute impact strongly varies among the model studies, depending on the percentage of all dwellings and other land-use 
categories that vary geographically. This percentage is very much related to the time horizon of studies, as locations for future urbanisation are fixed for many years in advance, for example, some 10-15 years for the Netherlands. The longer the time period, the more important land-use policies are, both in absolute terms and terms relative to other policies. Furthermore, the model simulations demonstrate the relevance of geographical scale in the analysis of impacts of urbanisation patterns on travel (Van Wee, 2002). For example, Verroen et al. (1995) showed that positive effects of building new residential locations at the edge of town could occur outside the Randstad, but for the larger cities, this effect could be limited or non-existent. This is likely caused by distances from the new residential areas to the city centres being too great to have a positive impact, since distances are too great even for people to cycle.

\subsection{Other impacts}

Although the research context is often termed the analysis of environmental impacts of transport, research in the Netherlands on compact urbanisation has focused primarily on travel behaviour indicators, land cover needed for urbanisation and preservation of open space. If environmental indicators are used, energy use and/or emission levels are, virtually without exception, the only environmental indicators used. In a review of Dutch studies on the environmental impacts of compact urbanisation, Van der Waals (2000) concluded that little attention had been paid to other environmental impacts such as local air pollution, noise and habitat fragmentation of nature conservation areas. Some ex post evaluations have examined relationships between urban form and preservation of open space in the Randstad. Dieleman et al. (1999) concluded that it would be difficult to give an unqualified answer to the question of the success or failure of compact urban policy in the Randstad from the perspective of urban form, the outcome being a mixed bag. On the one hand, deconcentration of population and economic activities has proceeded, while, on the other, more than half a million dwellings were built in the designated urban growth centres. Furthermore, urban sprawl was limited by restricting the growth of villages in the Green Heart, reducing the rate of population growth in rural municipalities. Without compact urban growth, the Green Heart would almost certainly have been invaded by more scattered, new residential and industrial urban functions. Hence, compact urbanisation policies have been successful, but not optimal (see also Van der Straten et al., 1996)

Some research has also been conducted on the impacts of urbanisation patterns on natural environments in the Netherlands. Scenario studies have been conducted to examine the effects of future urbanisation patterns on the fragmentation of natural areas, e.g. Farjon et al. (1997), De Nijs et al. (2004). The obvious conclusion from these studies is that the habitat area of animal species would be reduced under dispersed urbanisation compared to compact urbanisation patterns. 
In the Netherlands and elsewhere, there is very little knowledge on the links between compact urban development, and social and economic impacts. Overall social, quality-of-life issues, and social equity effects, of compact urbanisation have received limited attention (see Burton, 2000) for an overview. Even fewer efforts seem to have been made to examine the economic impacts of land-use policy strategies. In the Netherlands, the only example of an economic appraisal study is an ex ante evaluation of the land-use and transport impacts of alternative future urbanisation scenarios for the Dutch Randstad area (ECORYSNEI, 2004). This study examined the costs and benefits of future compact and dispersed urbanisation scenarios, including travel costs, housing benefits and (monetary valuations of the) preservation of open space. However, the methodology and results of the study have been heavily criticised. To our knowledge, few additional studies have been undertaken elsewhere to examine the economic impacts of land-use policy strategies. One of the few examples is the EU PROPOLIS project (Lautso et al., 2003), in which a cost-benefit analysis was conducted to evaluate the economic impacts of urban land-use and transport policy strategies in seven European cities. However, the economic impacts include only transport benefits and costs; effects in the land-use system are also beyond the scope of the evaluation model, e.g. the valuation of housing benefits and losses of open space and natural environments.

\subsection{Synthesis of Dutch evidence and transferability to other countries}

Dutch empirical and model studies examining land-use patterns have primarily dwelled on the link between land-use patterns and travel behaviour, mainly through cross-section comparisons of residents' travel behaviour differences in neighbourhoods, cities or regions having different land-use characteristics. Generally, there is enough evidence to show that land-use variables influence travel behaviour on several geographical scales, but the strength of the relationship differs considerably between studies. There are several reasons for the differences in results, e.g. methodological weaknesses, data limitations and the spatio-temporal settings of the data (Van Wee, 2002; Schwanen, 2003; Meurs \& Van Wee, 2004). Many improvements can be made in the empirical analysis of relationships between land use and transport, including multi-level regression models and structural equation models, which offer better opportunities to analyse complex relationships between variables (Meurs and Van Wee, 2004). Recent empirical studies using these advanced multi-level regression models in the Netherlands (Snellen, 2001; Schwanen, 2003) found a relatively small impact of land use on travel behaviour. It thus seems that when methodologically sound research methods are used, empirical evidence in the Netherlands supports, no more than other countries, a strong relationship between land-use patterns and passenger travel. This seems rather surprising. One would expect the Dutch situation to show a clearer relationship than, for example, the American one, given the long tradition in spatial planning and massive interventions in urban 
development in the Netherlands. Explanations for the relatively weak link between land use and travel behaviour derived from Dutch empirical studies may be related to the geographical and temporal settings of the studies. Firstly, different study areas in the Netherlands do not always strongly differ with respect to the most important land-use factors that influence transport, such as densities and the level of mixed use. For example, the differences between Greenfield locations near existing cities ("VINEX" locations) and other residential areas at the edge of towns in the Netherlands is limited. Therefore, travel behaviour differences of residents are small (Hilbers et al., 1999). Secondly, most researchers use cross-section data to find out if land use affects travel behaviour. Few empirical studies on the effects of land-use policies have been carried out using long-term longitudinal data, such as panels. An example of such a long term study is given by Meurs and Haaijer (2001), who found significant impacts of the neighbourhood design on travel behaviour using a 10-year time interval of the Dutch population.

Results from Dutch model simulations, carried out for the Netherlands as a whole or part of the country, demonstrate the relative impact of land use on transport to be important. The studies conclude without exception that land use has a relatively strong impact on transport. The model simulations show the relevance of different spatial-temporal settings. The longer the time period and the greater the differences in land-use factors, the more important land-use policies are, both in absolute terms and relative to other policies. However, the models used in existing Dutch scenario studies are likely to overestimate the impact of land use on transport for several reasons (Van Wee \& Van der Hoorn, 2001). Three important reasons are: (1) the models do not incorporate time budgets, making potential variations in average travelling time per person as modelled possibly bigger than in practice, (2) the models are based on cross-section data, which generally overestimate impacts of changes, (3) bias within homogeneous population groups due to differences in lifestyles, attitudes or preferences for modes that are not considered. Kitamura et al. (1997) show, for example, that residents' attitudes related to urban life are more strongly related to travel than the land-use characteristics. Van Wee et al. (2003) show that preference for certain modes influence travel behaviour and choice of residential location. However, existing Dutch model studies may also have underestimated the impact of land use on transport. That is, they have not examined land-use patterns which had encouraged car use beforehand. Compared to the decades of compact urbanisation policies, it is much easier to develop land-use policies that have much "worse" impacts on travel behaviour than "better" results. For example, if urbanisation in the Netherlands from the 1960s had developed similarly to suburbanisation in the United States - with very low housing densities in suburbs far away from public transport, cities and town centres with shops and services for non-daily needs the level of car use today would have been significantly greater that it is (Van Wee, 2002). 
Can the results of Dutch research on compact urbanisation be used for policy making in other countries? The answer to this varies. First, there may be sharp differences in urbanisation and transportation characteristics between countries that will affect the strength of relationships, and secondly, planning concepts and interpretations used in spatial planning differ which makes conclusions difficult to translate to policy making in other countries. Here, we will briefly explain the two differences. Firstly, as already noted in Section 2, the Netherlands has a distinctive polycentric urbanisation structure with several relatively small cities with relatively high densities. As a result, inter-urban and inter-regional travel is relatively more important in the Netherlands than in monocentric metropolitan areas in the for example the U.S., London, Paris or Berlin. This probably makes the car a more attractive alternative, other relevant factors remaining constant (Van Wee and Maat, 2004). However, we expect the sign of the relationship between compact urbanisation and travel as found in the Netherlands to be the same as in other countries, but the strength of the relationship might differ. Secondly, there is a clear difference in geographical scale and interpretation of spatial planning concepts between Dutch and other European research and that of the United States. In the USA and Australia the debate is mostly concerned with the design of neighbourhoods, using such spatial planning concepts as Neo-Traditional Design, Transit-Oriented Development and New Urbanism (e.g. see Cervero, 2004). These concepts focus on the benefits of urban development, such as walkable neighbourhoods, orientation to public transit systems and integration of different land uses at the neighbourhood level. In the Netherlands and other European countries, e.g. the United Kingdom, the compact city debate is mostly concerned with the development of housing, employment and services close to each other at the regional level (e.g. see Headicar, 2004). Moreover, the interpretation of the compact city concept differs. A compact city in the United States, for example, may be a low-density area in the Netherlands, since densities in residential areas in the Netherlands are much higher than in the United States. Compact is a relative term, which makes conclusions on the impact of compact urbanisation difficult to translate to other countries.

From the literature it is clear that, even after many years of scientific and political debate, the effects of Dutch compact urban development policies are still not very well understood, and that there is still no consensus on the benefits of this development. Two main gaps in the knowledge about the effects of compact urban development can be identified from the literature. Firstly, existing empirical and model simulations may have underestimated the impacts of compact urbanisation on transport because land-use patterns that encourage car travel beforehand are not considered. Secondly, research in the Netherlands and elsewhere has primarily focused on empirical research on the links between land use and travel behaviour. Analysis of impacts according to a broad range of land use, transport, accessibility and related societal and ecological impacts is lacking. 


\section{Modelling and Appraisal Methodology}

\subsection{Introduction}

This study presents an initial attempt to establish a methodology and evaluation framework for analysing the effectiveness of Dutch national spatial planning policies implemented in the $1970-2000$ period. The study consisted of three phases:

- In the first phase, a dynamic GIS-based, land-use transport interaction model, Environment Explorer (Engelen et al., 2003), was developed and applied in a study simulating the real-world land-use and transport developments in the Netherlands on a yearly basis from 1970 to 2000 (the calibration phase). Section 4.2 briefly describes the Environment Explorer.

- The second phase focused on the development of alternative land-use scenarios for Netherlands for the 1970-2000 period. Section 4.3 describes the scenario methodology while Section 4.4 presents the scenarios.

- In the third, and final step, the impacts of the reference and alternative landuse scenarios were computed and evaluated using the Environment Explorer for a range of land-use, transport, accessibility, social and ecological indicators. Section 4.5 presents the indicators used in this study. The results of the simulations are described in Section 5.

\subsection{The Environment Explorer 1970-2000}

The ultimate goal of analysing the impacts of compact urbanisation policies implemented in the Netherlands would be an in-depth appraisal of land-use, transport and accessibility effects and the integrative impacts on the economy, society and the environment. This makes the case for using a land-use/transportinteraction modelling framework. With this framework we can take full account of the complex interactions and synergies that might occur between land-use and transport changes, and consider an important range of the possible impacts arising from planning decisions in land use and transport. A dynamic GIS-based, land-use transport interaction model for the Netherlands, the Environment Explorer (Engelen et al., 2003), was applied in this study. So far, the Environment Explorer has been applied to forecast land-use developments in scenario studies (1995 to 2030, as in (e.g., see De Nijs et al., 2002). A new purpose-built version was developed in this study to simulate the period between 1970 and 2000.

The Environment Explorer consists of land-use and transport modules that are dynamically linked, thus allowing feedback processes. The transport module is a traditional "four-stage" transport demand model, in which the input is the spatial distribution of population and employment results from the land-use module. Likewise, the land-use module takes the accessibility measures available from the transport module as one of the factors determining the allocation of land. A short description of the two modules follows. 
The land-use model operates at three distinct levels of spatial aggregation: the national, regional (40 regions, called COROPS) and detailed local level (25 ha cells). Additionally, the land-use model produces results at a sub-regional level (345 zones) as input for the transport module. In this study, the development of population and economic activities by economic sector is exogenously defined at the national and regional level for the 1970-2000 period; data are taken from Statistics Netherlands. At the local level (351,000 grid cells of 25 ha each), the allocation of economic activities and people is modelled by means of the Cellular Automata model that runs on top of detailed GIS information (White et al., 1997). Cellular Automata account for the influence of the neighbouring activities within the surrounding grid cells. Location rules describe the relationships between the different forms of land use, classified in 10 (urban and non-urban) land-use categories, six of which are modelled dynamically. Land-use allocation depends on four elements: (1) cellular accessibility, based on zonal accessibility levels by car and public transport for different activities, and local distances to road and rail infrastructure, railway stations, motorway approaches and exits; (2) the physical suitability of cells to support a land-use function,; (3) the land-use zoning or institutional suitability, as described in national or regional land-use policy plans (e.g. nature conservation areas), and (4) the neighbourhood effect, which is the combined effect of attraction and repulsion by the functions present in the neighbourhood. The strength of the interactions is articulated in rules, and is a function of the distance separating the different functions within the neighbourhood. The neighbourhood consists of all cells found within a radius of 4 $\mathrm{km}$. On the basis of these four elements, the model calculates the transition potential for each cell and function for each simulation step. In the course of time and until regional demands are satisfied, cells will convert to the land-use function for which they have the highest potential. A simulation step has been made on a yearly basis.

A traditional "four-stage" transport demand model estimates car and public transport travel for an average working day (24-hour period) for 345 transport zones for one year, incorporating congestion effects. The transport model simulates a land-use transport-system equilibrium state within one year, providing output to the regional and local land-use models for the subsequent time period. The land-use module uses potential accessibility measures (jobs, population and recreational facilities) by transport analysis zone as input for the computation of cellular accessibility values. In this study, the transport module is run less frequently than the land-use module (i.e. every five years instead of every year) to simulate time lags in interaction between transport and land use.

In the calibration phase of model, the model parameters are adjusted to simulate actual land-use and passenger transport developments for the 1970 to 2000 period. The calibrated model simulation is used as the reference scenario in the scenario study (phase 2). The land-use sub-model uses yearly population and employment data at the regional level for the period 1970-2000 and land-cover data (at the 25 ha grid cell level) for 1970 as input. The land-cover data were 
purpose-built using 1:50,000 topographic maps for the whole of the Netherlands and additional land-cover data (Kramer \& Knol, 2003). To calibrate land cover developments at the grid cell level, the location rules from the Cellular Automata model are adjusted to reproduce land-use cover data for the year 2000. The contour of urban and natural conservation areas for the year 2000 are used as land-use zoning maps to establish a good model fit. Road infrastructure networks were constructed for each five-year period the transport model is run using road maps and 1986 and 1995 infrastructure networks from the National Model System (NMS) (Gunn \& Hoorn, 1998). Public transport level of service matrices were constructed using 1973, 1983, 1993 and 1986 and 1995 travel time data from the SMART model (Smits et al., 1996) and the NMS, respectively. The transport model is calibrated to reproduce aggregate passenger mobility trends for the 19702000 period (i.e. national car and public transport trip length and volumes) and more detailed travel behaviour data for the year 1995 (road traffic and congestion levels) ${ }^{1}$.

\subsection{Scenario methodology}

The main goal of this study was to analyse the bandwidth in potential impacts if the compact urbanisation policies from the last 30 years in the Netherlands had not been implemented. A scenario approach was chosen as research methodology, with arguments explained below.

Envisioning how a region or country would have looked like under policy regimes other than the ones actually implemented is highly speculative and subject to many uncertainties. In the Netherlands, migration trends have been strongly influenced by the compact urbanisation policies and massive policy interventions since the 1970s. For example, regions in the Green Heart of the Randstad and regions where large nature conservation areas are located, such as the Veluwe National Park (see Figure 1 for a map) have exhibited a relatively modest population growth as the result of restrictive land-use zoning policies. However, Dutch housing surveys show that more than one-third of the households located in central urban areas considering relocation (within 2 years) would prefer to live in rural and green housing environments (Ministry VROM, 2003). The modelling of location behaviour of households and firms under radically different land-use policy regimes is outside the scope of existing models in the Netherlands. The strength of behavioural responses in these models is calibrated on historical data to match patterns in the real world. Such a model would also be very difficult to develop because the model can not be calibrated or validated and basic plausibility tests can thus not be performed.

The scenario approach was popularised by Shell in the 1970s as a business tool to allow it to make business plans "without having to predict developments everyone thought of as unpredictable". Although scenario building is most commonly associated with future research, it can also be applied as an ex post research method. The starting-point for a scenario study is to identify 
"predetermined" and "undetermined" elements. The predetermined elements are the same in each scenario, while the undetermined elements are elaborated in several ways depending on possible future developments (Van der Heijden, 1996). Here, the predetermined elements are socio-economic and demographic developments at the national level, and the undetermined element is the regional distribution of population and employment (by economic sector). In this study, we assume that location preferences of households and firms at the local neighbourhood level, as articulated in the location rules of the Cellular Automata model of the Environment Explorer, do not change as the result of alternative land-use policies. Thus, we assume that land-use policies do not affect people's housing preferences, e.g. households will still prefer housing locations at close proximity to urban and natural environments as shown in current housing preference studies, whereas residential location choices are influenced by land-use policies given available housing supply

Two alternative land-use scenarios were constructed for the 1970-2000 period, differ in the assumptions about the regional distribution of population and employment to account for the uncertainty in behavioural responses of households and firms. The scenarios were developed using an expert-based method of scenario construction. Since the Delphi method for scenario construction, using several rounds of questionnaires with controlled feedback, is known to be quite time consuming (e.g. Shiftan et al., 2003), we used a simplified Delphi method. In the first round, a full day workshop was organised to achieve early consensus among (a group of 10) Dutch spatial planning and transport experts. The participants received general information about the project beforehand and discussed the scenarios in qualitative terms during the workshop. Afterwards, the scenario narratives were translated into quantitative scenario descriptions. In a second round, the quantitative scenario information was sent (as a spreadsheet file) to the experts who were then able to alter the absolute and relative changes of population and employment (by economic sector) by (COROP) region for the year 2000, with fixed totals at the national level. Finally, the expert's changes made were incorporated into the final scenarios (described in section 4.4.).

\subsection{Scenario description}

The Liberal Urbanisation Scenario reflects land-use developments when no restrictive spatial policies are assumed to prevent urban sprawl and protect open agricultural and nature conservation areas against urbanisation in the 1970-2000 period. In this scenario, it is assumed that all locations, except water surfaces, are physically suitable for urbanisation. Furthermore, it is assumed that due to a lack of housing regulations and restrictions, average housing densities of new residential areas will be lower than in the reference case. We assume that no new high-density housing locations are realised after 1970, which roughly results in a $10 \%$ decrease in average housing densities compared to the reference scenario in 2000. Road infrastructure developments are assumed to be the same as for the 
reference case, but railway stations built to connect the (Third and Fourth Report's) new towns to the railway network are not realised if these towns are not (endogenously) developed. In this scenario, population and employment developments at the regional level (40 economic regions) are assumed to be the same as the reference scenario. Hence, new housing and employment locations may be (in comparison to the reference scenario) allocated at different locations within the same region, but interregional migration of population and firms is not assumed. In reality, however, interregional migration can be expected as the result of the radically different land-use policies. This effect is reflected in the following scenario.

The Liberal Urbanisation \& Migration Scenario follows the same assumptions as the Liberal Urbanisation Scenario, but is combined with assumptions on interregional migration of population and firms. The main assumptions in this scenario on population and employment developments are that:

- Population and employment growth (of service and socio-cultural sectors) between 1970 and 2000 will be concentrated in well-accessible central and central-eastern regions in the Netherlands. Population levels will (compared to the reference scenario in 2000) increase up to $50 \%$ in the city of Utrecht region, and the Green Heart and Veluwe regions;

- Population levels stabilise at 1970 levels in peripheral areas (northern, eastern and southern provinces) in the Netherlands and the Amsterdam region. The service sector will decrease (up to 50\% compared to the reference case in 2000) in peripheral regions in the Netherlands. Population levels will decrease relatively sharply in the Flevoland regions since the major (new) towns (e.g. Almere) will hardly be developed.

- The major cities (Amsterdam, Rotterdam, The Hague) will exhibit a population decline (up to $10 \%$ ) due to the absence of urban renewal policies and reallocations to rural and green housing environments;

The results of the assumptions are visualised in Figures 2 and 3. The figures show the population and employment levels by COROP region for the Reference Scenario and the difference in population and employment levels between the Liberal Urbanisation \& Migration Scenario and Reference Scenario.

\subsection{Indicators}

A broad range of indicators, including land-use, transport and accessibility effects should be used to study the full impact of land-use and infrastructure policies, and their final impacts on the economy, society and the environment. Our main goal here is to present a range of relevant impacts, focusing on the most distinctive land-use, mobility, accessibility, social and ecological indicators (Table 1). The indicators used are output from the Environment Explorer, or are computed using data from the land-use and transport-model output. The land-use and transport indicators are seen as intermediate or background indicators that help us to 
understand and explain the final ecological and social impacts. As accessibility impacts strongly depend on the measure used (see Geurs \& Van Wee (2004) for a review), several accessibility measures can be estimated here. The infrastructurebased accessibility measures of "congestion levels" and "average car travel speed" describe the functioning of the road network and thus show only transport-system changes. The activity-based accessibility measure "potential accessibility to jobs and population" show the level of access to spatially distributed activities and thus the combined effect of land-use and transport-system changes.

The Environment Explorer estimates land use, activities, noise levels and fragmentation of nature areas at the resolution of 500-m grid cells. This spatial resolution is, given the data availability, considered appropriate for modelling land-use processes at spatial scales from the neighbourhood level and upwards, but not necessarily on the lowest spatial scales, such as street level. It is also sufficient for analysing developments and impacts of land-use and transport policies and scenarios but it is too coarse for exact measurements of environmental impacts at the local level; this would require a spatial resolution of $100-\mathrm{m}$ grid cells or - especially for indicators such as the concentrations of pollutants and noise - preferably smaller. This firstly implies that the spatially differentiated environmental indicators estimated in this study, i.e. noise levels and wildlife habitat fragmentation, are no more than rough estimations of developments and cannot be used for detailed analysis at the local level. Secondly, we are not able to estimate impacts of land use via travel behaviour on concentrations of pollutants because this would require high resolution air dispersion models calculating immisions from emissions.

Furthermore, the estimation of total economic costs and benefits of landuse and infrastructure investments (e.g. housing and infrastructure investment costs, \& government benefits) is beyond the scope of this study. This also holds for the final aggregate score of impacts using social cost-benefit-analysis (SCBA) or multi-criteria analysis (MCA). Obviously, a full ex-post evaluation of 30 years of land-use policies on all relevant indicators would be even more complex and also beyond the scope of this study. This would imply a full appraisal of land-use and infrastructure policies implemented in the last 30 years, and an extension of the modelling and evaluation framework.

\section{Results}

\subsection{Land-use impacts}

In the last three decades the Netherlands has seen a process of regional suburbanisation and national deconcentration of urbanisation (WRR, 1998). The reference scenario shows a sharper population growth between 1970 and 2000 in suburban areas (35\% increase) and peripheral areas (25\% increase) than in central urban areas (5\% increase). However, the compact urbanisation policies implemented since the 1970 s to prevent urban sprawl have successfully 
moderated urban sprawl. In the reference scenario, further urbanisation of rural areas is restricted and controlled by land-use regulations.

Firstly, Liberal Urbanisation scenarios, where no land-use restrictions are assumed, are shown in Table 2 to exhibit a much higher level of suburbanisation and more disperse urbanisation patterns. Population groups shift from central urban areas to mainly rural, peripheral regions (for example, in the Green Heart); this effect is even more strongly felt in the Liberal Urbanisation and Migration Scenario. Secondly, the compactness of the built-up area, computed as the total surface of unbroken urbanised area within a certain radius for each grid cell, is clearly sensitive to different urbanisation patterns. The Liberal Urbanisation scenarios show much more dispersed urbanisation patterns than realised in the past. Between 1970 and 2000, the compactness of the urban area decreases by about $20 \%$ the reference scenario, whereas the Liberal Urbanisation scenarios exhibit a $30-40 \%$ decrease for the same period (10-20\% decrease compared to the reference scenario in 2000). Note that the compactness of the urban area is greater in the Liberal Urbanisation \& Migration scenario than in the Liberal Urbanisation Scenario. The shift of population and firms to central regions in the Netherlands reduces urban sprawl in peripheral regions and increases urbanisation near existing small villages and towns in central regions, which increases the surface of unbroken urban area compared to the Liberal Urbanisation scenario.

Figure 4 shows, zooming in on Randstad Area, the urbanisation pattern for the reference and Liberal Urbanisation \& Migration scenario for the year 2000. Here, major urbanisation around existing small towns and villages in the Green Heart of the Randstad is first shown to create ribbon development at locations well accessible by car, mainly around the major motorway network. Secondly, urbanisation is seen to increase sharply in and around nature areas, in particular in the southern parts of the Veluwe National Park, locations close to both nature areas and urban facilities.

\subsection{Transport impacts}

As in most Western European countries, passenger mobility in the Netherlands has grown very sharply in the last decades, mainly as the result of socio-economic and demographic changes. Korver \& Vanderschurven (1995) examined explanatory factors for car use growth in the Netherlands for the period 19701995. In this period, car use increased by almost $150 \%$ and public transport use by about $90 \%$. About half the car use growth in this period was explained by sociodemographic changes (population and household growth and changes in composition), about one-quarter by income and car ownership growth, and the remaining quarter by infrastructure expansions and land-use changes. About 10$20 \%$ of the growth in car use can be explained by the substantial road network since the 1970s, e.g. construction of orbital roads around major towns, which reduced interregional travel times by about 50\% (Ploeger \& Van der Waard, 1997). 
Results from the Liberal Urbanisation scenarios seem consistent with these figures; showing that the influence of urbanisation patterns on national passenger mobility development is significant, but modest. The Liberal Urbanisation scenarios show, at the national level, roughly about 5-10\% more car use (passenger kilometres travelled) and 5-15\% less public transport use. The effects are most pronounced for the Randstad area, where car use increases by about 10$25 \%$ and public transport use decreases by about 5-20\%. Note, however, that the transport impacts estimated here are likely to be underestimated, especially for the more extreme Liberal Urbanisation \& Migration scenario. The forecasted transport impacts are the result of longer average trip distances and (to a lesser extent) mode shifts from public transport to the car. Hence, potential mode shifts to non-motorised modes are not included; an important mode in urban areas in the Netherlands. Moreover, we have not incorporated changes in car ownership. In reality, however, the land-use changes envisioned are likely to have an impact on car ownership.

The increase in car traffic in the Randstad, the most urbanised and congested region in the Netherlands, clearly increases congestion levels in the Liberal Urbanisation scenarios. Average car travel speed on the main road network is reduced by roughly 5 to $20 \%$ compared to the reference scenario. The proportion of the road network with modest and severe congestion (defined as a ratio of traffic flow to road capacity greater than 0.5 ) increases by 25 to $60 \%$, respectively, for the Liberal Urbanisation and Liberal Urbanisation \& Migration scenarios compared to the reference scenario. Note that the forecasted accessibility impacts are only a rough estimation and do not fully reflect all transport-system developments. The transport model used does not include a full urban road network and does not model local traffic, furthermore, it uses a relatively simple traffic assignment and congestion computation method.

\subsection{Ecological and social impacts}

Table 3 provides an overview of changes in the ecological and social indicators for the Liberal Urbanisation Scenarios, relative to the Reference Scenario for 2000 .

\section{Ecological impacts}

$\mathrm{CO}_{2}$ emissions from transport are directly related to car-use levels and show the same relative development, as vehicle type choice or fuel efficiency impacts are not assumed. The impact of the Liberal Urbanisation scenarios on noise levels in nature conservation areas is, on average, very small for the national level. Note, however, that the impacts are expressed as one on the logarithmic $\mathrm{dB}(\mathrm{A})$ scale. There are also strong regional differences included under the national average, in particular for the Liberal Urbanisation \& Migration Scenario, where a strong redistribution of traffic flows is forecasted. Noise levels in the nature areas located in the central and central-eastern regions of the Netherlands (Utrecht, Veluwe 
National Park) increase sharply in this scenario (up to 3-5 $\mathrm{dB}(\mathrm{A})$ along motorways), whereas noise levels in peripheral regions are sharply decreased.

Nature conservation areas in the Netherlands are strongly fragmented which is not surprising as the Netherlands is a densely populated country with an extensive infrastructure network. The degree of habitat fragmentation computed here is sensitive to (a) the total surface of natural environments and (b) the degree of fragmentation due to built-up and intensively cultivated areas, the location of road infrastructure and traffic levels at the roads. The overall size of Dutch nature conservation areas is relatively small, and the largest nature conservation areas are clearly fragmented by road infrastructure. However, without restrictive land-use policies, the degree of fragmentation would have been higher. Zooming in on the central regions of the Netherlands, Figure 5 shows the increase in habitat fragmentation for the Liberal Urbanisation \& Migration scenario compared to the reference scenario for 2000. The degree of habitat fragmentation clearly increases in the nature conservation areas located in central and central-eastern regions, in particular, for the Veluwe National Park where urbanisation and traffic levels increase.

\section{Social impacts}

Potential accessibility to social and economic opportunities (population and jobs, respectively) by car and public transport, and proximity to green areas from residential areas (i.e. within a walking distance of $5 \mathrm{~km}$ ) are estimated here for examining social impacts related to accessibility changes. Table 3 shows that car accessibility to jobs and population decreases significantly; in particular for the Liberal Urbanisation \& Migration Scenario. This is the result of increased (average day) car travel times and the regional distribution of the population and jobs from central urban areas (which have the highest potential accessibility levels) to suburban and rural areas. Surprisingly, public transport accessibility levels slightly increase in both liberal urbanisation scenarios, while the decrease of job and population accessibility in central urban areas are more than compensated by increases in suburban and rural areas. In the Liberal Urbanisation \& Migration Scenario, public transport accessibility improves, mainly as the result of the population and job shift to central regions in the Netherlands, regions relatively well-served by public transport, particularly in the city of Utrecht region. As expected, the Liberal Urbanisation scenarios improve access to green areas because more dwellings are developed at close proximity to nature areas.

However, the increase for the Liberal Urbanisation \& Migration scenario is somewhat smaller than for the Liberal Urbanisation scenario because more nature area is replaced by residential area (the total surface of nature area is reduced by 5 and $1 \%$, respectively). Furthermore, the total time spent in traffic increases in both Liberal Urbanisation scenarios. This is interpreted as a social indicator, reflecting the efficiency of the land-use/transport system, incorporating congestion effects and the efficiency of the spatial structure (see also Lautso et al., 2003). Transport here, is seen as a means of achieving other goals, and not as an 
goal in itself. Time spent in traffic can thus be regarded as a lost opportunity. Clearly, the two Liberal Urbanisation scenarios result in less efficient landuse/transport systems.

The Liberal Urbanisation scenarios have significant impacts on traffic noise levels in residential areas, with the total surface of residential area with noise levels greater than $55 \mathrm{~d}(\mathrm{~B}) \mathrm{A}$ increasing by 5 to $7 \%$. This is the result of increased traffic levels, but also of the increase in the total surface of urban area. In reality, the increase in noise levels will be lower, as the noise emission model does not incorporate the impact of noise mitigation measures (such as silent asphalt and noise barriers) taken in residential areas.

\section{Conclusions and discussion}

There is a wide array of literature on the effects of compact urban development, however, benefits are still not very well understood and there is still no consensus on them. From the literature we identified two main gaps in knowledge about the effects of compact urban development. What is lacking are, firstly, insights into how a region or country would have appeared under policy regimes other than the one realised and, secondly, a broad evaluation of relevant land-use, transport, accessibility and related societal and ecological impacts.

In this paper we made an initial attempt to fill these two gaps using a study for the Netherlands, in which we try to establish a methodology and evaluation framework for analysing the effectiveness of Dutch national spatial planning policies implemented between 1970 and 2000. Firstly, a high-resolution land-use transport-interaction model was developed and applied to simulate real world land-use and transport developments in the Netherlands from 1970 to 2000 on a yearly basis. Secondly, alternative visions were developed to describe what the Netherlands would have looked like in the year 2000 if the massive interventions in urban development and restrictive land-use regulations had not been implemented. To account for the uncertainty in behavioural responses of households and firms, two alternative "liberal urbanisation" scenarios were constructed using a expert-based scenario construction method: one, assuming no changes in regional distribution of population and employment, and the other, assuming that population and employment shifts from peripheral to wellaccessible central and central-eastern regions in the Netherlands. The scenarios thus present a bandwidth in likely effects. Thirdly, and finally, the impacts of the urbanisation scenarios were computed and evaluated using a range of land-use, transport, accessibility and related social and ecological indicators.

The analysis shows Dutch spatial planning to have been successful. Without compact urban development policies, urban sprawl would likely have been greater, resulting in less compact urbanisation patterns, more car use at the cost of alternative modes, higher emissions and noise levels in residential and nature areas, higher congestion and lower accessibility levels, along with a stronger fragmentation of wildlife habitats. In conclusion, land-use policies as 
implemented in the 1970-2000 period, have certainly contributed to the land-use and transport-related intentions of the Dutch national government. In other words, they have contributed to open space conservation, and resulted in less car use and fewer related environmental impacts than under a more liberal land-use policy.

Academic research on the impact of urbanisation patterns on travel behaviour focuses on (i) empirical studies linking land-use patterns and travel, primarily through (cross-section) comparisons of resident's travel behaviour in differences in neighbourhoods, cities or regions having different land-use characteristics, and (ii) model simulations of different future land-use scenarios. From the literature it is clear that both approaches have their merits and demerits. Methodologically sound empirical studies in the Netherlands show that land-use variables significantly affect travel indicators but the effects are not very substantial. However, do these studies measure the full potential impact of different urbanisation patterns? Empirical studies may be biased as a result,on the one hand, of their geographical and temporal settings and on the other because of methodological characteristics.

Urban areas selected for empirical studies in the Netherlands may not differ very strongly with respect to the most important land-use factors that influence transport, such as densities and the level of mixed use. The reason is that for 30 years Dutch governments have strived for compact urbanisation in various forms and realised massive interventions in urban developments. Therefore landuse patterns that encourage car travel beforehand have not been realised and can by definition not be included in empirical analysis, so travel behaviour differences derived in empirical studies may be small. Alternatively, empirical studies may involve international case study comparisons of regions or cities with more distinctive land-use characteristics. Banister et al. (1997) for example compares a Dutch city with five cities in the United Kingdom. Significant relationships are found between energy use in transport and land-use characteristics such as density, size and amount of open space. However, compatibility problems inevitable in case study comparisons make it difficult to establish definitive relationships. These problems are related to the fact that travel behaviour is the result of many determinants, and land-use determinants are only of relatively limited importance compared to, for example, the impact of travel costs, infrastructure and public transport service availability, demographic variables and incomes.

Model simulations as conducted in this study are more capable of analysing the full potential impacts of different urbanisation patterns, since landuse variables that affect travel indicators can be substantially changed into long term scenario studies. However, state-of-the-practice land-use/transport models are likely to overestimate the impact of land use on transport for several reasons, in particular the exclusion of time budgets and biases within homogeneous population groups due to differences in lifestyles, attitudes or preferences for modes. On the other hand, the land-use/transport model used in this study is likely to underestimate behavioural responses. In particular, location preferences of 
households and firms are assumed to be the same under different planning regimes, and the transport model does not incorporate feedback links to car ownership levels and trip generation, and does not model use of non-motorised modes. The effect of these biases on the land use and transport impacts estimated in this study is difficult to state. We expect the sign of the relationships to be correct, but more research will be necessary to examine the size of the effect. To validate the results from the model simulations, future research may be directed towards comparative analysis of areas or cities that have undergone different planning regimes in the past using longitudinal travel behaviour data.

The ultimate goal of analysing the benefits of compact urbanisation policies implemented in the Netherlands would be an in-depth appraisal of land use, transport and accessibility effects, and the integrative impacts on the economy, society and the environment. In this paper we focused on the most distinctive land-use, mobility, accessibility, social and ecological indicators using a high-resolution land-use/transport- interaction model. More research will be necessary to analyse the social and economic costs and benefits of compact urbanisation policies. This includes a cost-benefit analysis and/or a multi-criteria analysis to aggregate the impacts to the different dimensions of sustainability. Initial attempts to create such a framework were, for example, demonstrated by Lautso et al. (2003).

The debate on compact urban development is broader than a discussion of the benefits only. Breheny (1997), for example, suggests that compact urban development should be subject to three types of tests: veracity, feasibility and acceptability. In this article we extended the discussion on the veracity case - the benefits of compact urban development. Less attention in the literature is often paid to the other two aspects. Breheny (1997) raises doubts on the feasibility of compact urbanisation as a planning concept considering economic, technical and political dimensions, and particularly the acceptability of higher densities to many urban residents in the UK. In the Netherlands, the acceptability of compact urbanisation as a planning concept has been under discussion since the late 1990s. Several publications called for a relaxation of national regulations and reducing supervision on local authorities (decentralisation) to facilitate the realisation of residential housing preferences. Indeed, housing preference studies show that residents prefer low density and green suburban residential areas. However, as shown in this study, building in low densities also results in less accessibility to opportunities and to the public transport system, a larger demand for space and less open space. So far, there is little knowledge on how people value such items. Clearly, the inclusion of feasibility and acceptability issues in the debate on compact urbanisation will present new research challenges.

\section{Acknowledgements}

Earlier versions of this article were presented at the World Conference on Transport Research (WCTR), Istanbul, 4-8 July 2004, and the European Transport Conference (ETC), Strasbourg, 8-10 October 2003. We have benefited from the 
comments of participants at these conferences. Furthermore, we thank the Transport Research Centre of the Dutch Ministry of Transport, Public Works and Water Management (AVV) and TNO Inro for allowing us to use data from the National Model System and the Smart model for development of the Environment Explorer.

\section{Footnotes}

${ }^{1}$ Since travel behaviour data are lacking, passenger mobility trends for the 1970-1985 period are based on trend extrapolations. Detailed yearly travel behaviour surveys (the Dutch National Travel Survey - OVG) have been conducted since 1985.

\section{References}

Anderson, W.P., P. S. Kanaroglou, E.J. Miller (1996) Urban Form, Energy and the Environment: A Review of Issues, Evidence and Policy. Urban Studies, 33( 1), pp. 7-35.

Badoe, D.A., E.J. Miller (2000) Transportation-land-use interaction: empirical findings in North America, and their implications for modeling. Transportation Research Part D, 5, pp. 235-263.

Bagley, MN, PL Mokhtarian (2002) The impact of residential neighborhood type on travel behavior: A structural equations modeling approach. Annals of regional science, 36(2), 279-297.

Banister, D. (1997). Reducing the need to travel. Environment and Planning B: Planning and Design, 24, 437-449.

Banister, D., S. Watson, C. Wood (1997). Sustainable cities: transport, energy, and urban form. Environment and Planning B: Planning \& design 24(1), 125-43.

Breheny, M. (1995). The compact city and transport energy consumption. Transactions of the Institute of British Geographers NS, 20, 81-101.

Breheny, M. (1997) Urban compaction: feasible and acceptable? Cities, 14 (4), 209-217.

Burton, E. (2000) The compact city: Just or just compact? A preliminary analysis. Urban studies, 37(11), 1969-2006.

Cervero, R. (2004) The Built Environment and Travel: Evidence from the United States. European Journal of Transport and Infrastructure Research, 3(2), 119-137.

Dieleman, F.M., M. Dijst, G. Burghouwt (2002) Urban form and travel behaviour: micro-level household attributes and residential context. Urban studies, 39(3), 507-527.

Dieleman, F.M., M.J. Dijst, T. Spit (1999) Planning the Compact City: the Randstad Holland Experience. European Planning Studies, 7(5), 605-621.

ECORYS-NEI (2004) KKBA verstedelijkingsalternatieven Randstad [Tentative cost-benefit analysis of urbanisation scenarios for the Randstad]. ECORYS Research, Rotterdam.

ECOTEC (1993) Reducing Transport Emissions through Planning Department of the Environment/Department of Transport/Ecotec Research \& Consulting ltd/Transportation Planning Associates, London.

Engelen, G., R. White, T. de Nijs (2003). Environment Explorer: Spatial Support System for the Integrated Assessment of Socio-economic and Environmental Policies in the Netherlands. Integrated Asessment, 4(2), 97-105.

Farjon, J.M.J., N.F.C. Hazendonk, W.J.C. Hoeffnagel (1997) Verkenning natuur en verstedelijking 1995-2020 [Exploring natural areas and urbanisation]. IKC Natuurbeheer, Wageningen.

Jenks, M., E. Burton, K. Williams (1996) The Compact City: A Sustainable Urban Form? London: E\&FN Spon.

Geurs, K.T., B. van Wee (2004) Accessibility evaluation of land-use and transport strategies: review and research directions. Journal of Transport geography, 12, 127-140.

Gunn, H., T. van der Hoorn (1998) The predictive power of operational demand models. A case study. 8th World Conference on Transportation Research, Antwerp. 
Hajer, M., W. Zonneveld (2000) Spatial planning in the network society - rethinking the principles of planning in the Netherlands. European Planning Studies, 8(3), 337-355.

Handy, S. (1996) Methodologies for exploring the link between urban form and travel behaviour. Transportation Research-D, Vol. 1(No. 2), pp. 151-165.

Headicar, P. (2004) The Contribution of Land Use Planning to Reducing Traffic Growth: the English Experience. European Journal of Transport and Infrastructure Research, 3(2), 137-154.

Hilbers, H., I. Wilmink, M.N. Droppert-Zilver (1999) Evaluatie mobiliteitsgedrag bewoners VINEX-locaties [Evaluation of mobility effects of VINEX locations. Final report]. Delft: TNO Inro.

Kitamura, R., P.L. Mokhtarian, L. Laidet (1997) A micro-analysis of land use and travel in five neighbourhoods in the San Fransisco Bay Area. Transportation 24, pp. 125-159.

Kockelman, K.M. (1997) Travel behavior as function of accessibility, land use mixing, and land use balance: evidence from San Francisco Bay Area. Transportation Research Record, 1607 , pp. 116-125.

Korver, W., M.J.W.A. Vanderschuren (1995) Monitoring van de mobiliteit: een analyse van invloedsfactoren achter de recente mobiliteitsontwikkelingen in het personenvervoer [Monitoring mobility: analysis of variables influencing passenger mobility developments]. Delft: TNO Inro.

Kramer, H., W.C. Knol (2003) Historisch Grondgebruik in Nederland: grondgebruik rond 1970 in 500 meter grids [Land use in the Netherlands: land use in 1970 in 500 meter grid cells]. Wageningen: Alterra.

Lautso, K., K. Spiekermann, M. Wegener, I. Sheppard, P. Steadman, A. Martino, R. Domingo, S. Gayda (2003). PROPOLIS. Planning and Research of Policies for Land Use and Transport for Increasing Urban Sustainability (PROPOLIS). Final Report. Helsinki: LT Consultants.

Meadows, D.H., D.L. Meadows, J. Randers, W.W. Behrens (1972). The limits to growth New York: Universe Books.

Meurs, H, R Haaijer (2001) Spatial structure and mobility. Transportation research part d transport and environment, 6(6), 429-446.

Meurs, H., B. van Wee (2004). Land use and Mobility: a Synthesis of Findings and Policy Implications. European Journal of Transport and Infrastructure Research, 3(2), 219-233.

Ministry of Economic Affairs (1999) Nota Ruimtelijk Economisch Beleid [Report on Spatial Economic Policy]. The Hague.

Ministry of Housing and Physical Planning (1966). Second Report on Physical Planning in the Netherlands, The Hague.

Ministry of Housing, Physical Planning and the Environment (1977). Derde nota over de ruimtelijke ordening. Deel 2: Verstedelijkingsnota. [Third Report on Physical Planning. Part 2: Urbanisation Report], The Hague.

Ministry of Housing, Physical Planning and the Environment (1991) Fourth Report on Physical Planning in the Netherlands (Extra). Summary, The Hague.

Ministry of Housing, Spatial Planning and the Environment (2003). Beter Thuis In Wonen. Kernpublicatie WoningBehoefte Onderzoek 2002 [Housing Preference Survey Report 2002], The Hague.

Ministry of Housing, Spatial Planning and the Environment (2004). Making Space, Sharing Space. Draft Fifth National Policy Document on Spatial Planning, The Hague. Summary available at http://www.vrom.nl/international/

Ministry of Transport, Public Works and Watermanagement (1990) Second transport structure plan., The Hague.

Neass, P.(2004) Urban structures and travel behavior: experiences from empirical research in Norway and Denmark. European Journal of Transport and Infrastructure Research, 3(2), 155-178. 
Newman, P., J . Kenworthy (1989). Cities and automobile dependence: a sourcebook Victoria: Gower, Aldershot and Brookfield.

Newman, P., J . Kenworthy (1999). Sustainability and Cities. Overcoming Automobile DependenceWashington D.C.: Island Press.

Nijs, T.C.M. de, R. de Niet, L. Crommentuijn (2004) Constructing land-use maps of the Netherlands in 2030. Journal of Environmental Management, 72, 35-42.

Ploeger, J., J. van der Waard (1997). Waar komt de groei vandaan? De mobiliteit in kaart gebracht.[Where does the growth come from? Analysing passenger mobility growth]. In: Infrastructurele ontwikkelingen. Rotterdam: Transport Reserach Centre.

Ryan, S., M. G. McNally (1995) Accessibility of neotraditional neighborhoods: A review of design concepts, policies, and recent literature. Transportation Research Part A: Policy and Practice, 29 (2), 87-105.

Schwanen, T. (2003) Spatial variations in travel behaviour and time use. The role of urban form and sociodemographic factors in individuals' travel and activity pattern in the Netherlands. Utrecht: Utrecht University.

Shiftan, Y., S. Kaplan, S. Hakkert (2003) Scenario building as a tool for planning a sustainable transportation system. Transportation Research Part D: Transport and Environment 8(5), 323-342.

Smits, C.A., E.J. Verroen, H.D. Hilbers (1996) Smart 2.1. Technische documentatie, Delft: TNO Inro.

Snellen, D. (2001) Urban form and activity-travel patterns: an activity-based approach to travel in a spatial context. Eindhoven: Eindhoven University.

Spaans, M., J.J. Trip (2003) Vinexconventanten. Een evaluatie [Vinex agreements. An evaluation]. Stedebouw en Ruimtelijke Ordening(02), 48-50.

Stead, D., S. Marshall (2001) The relationship between urban form and travel patterns. An international review and evaluation. European Journal of Transport and Infrastructure Research, 1(2), 113-141.

Van der Heijden, K. (1996) Scenarios. The Art of Strategic Conversation. Chichester: John Wiley \& Sons, Ltd.

Van Straten, A., B.G. Strootman, M.G. Berkhof (1996) Het groene hart in retrospectief : evaluatie Groene Hartbeleid 1950-1995 [The Green Hart in retrospective: policy evaluation 19501995]. Report no. RPD 45B506, The Hague: Ministry of Housing, Physical Planning and the Environment.

Van Wee, B. (2002) Land use and transport: research and policy challenges. Journal of Transport Geography, 10, 259-271.

Van Wee, B., T. van der Hoorn (2001) Land-use impacts on passenger transport: a comparison of Dutch scenario studies. Transport and environment. in search of sustainable solutions. pp. 231-254, Northampton, MA, USA: Edward Elgar.

Van Wee, B., H. Holwerda, R. van Baren (2002) Preferences for modes, residential location and travel behaviour: the relevance for land-use impacts on mobility. European Journal of Transport and Infrastructure Research, 2 (3/4), 305-316.

Van Wee, B., K. Maat (2004) Land-Use and Transport: a Review and Discussion of Dutch Research. European Journal of Transport and Infrastructure Research, 3(2), 199-218.

Verroen, E.J., H.D. Hilbers, C.A. Smits (1995). Modeltoets Randstadvisie: de resultaten [Model Evaluation of the Randstad Scenarios: the Results]. Delft: TNO

VROM (2004). The National Spatial Strategy. Room for development. Summary. The Hague: Ministry of Housing, Physical Planning and the Environment. .

VROM Council (1999) Mobiliteit met beleid [Mobility with policy]. Advice 017, The Hague: Council for Housing, Spatial Planning and the Environment.

Waals, J.F.M. van der (2000) The compact city and the environment: a review. Journal of Economic \& Social Geography, 91( 2), 111-121.

Wegener, M., F. Fürst (1999) Land-Use Transport Interaction: State of the Art. Deliverable D2a of the project TRANSLAND (Integration of Transport and Land use Planning). Berichte aus 
den Insititut für Raumplanung 46, Dortmund: Universität Dortmund, Insititut für Raumplanung.

White, R., G. Engelen, J. Uljee (1997) The use of constrained cellular automata for high-resolution modelling of urban land-use dynamics. Environment and Planning B: Planning and Design, 24, 323-343.

Williams, K., E. Burton, M. Jenks (2000). Achieving Sustainable Urban Form, London: E\&FN Spon.

WRR (1998) Ruimtelijke ontwikkelingspolitiek [Spatial development politics]. Wetenschappelijke Raad voor het Regeringsbeleid, The Hague. 
Table 1. Indicator list

\begin{tabular}{|c|c|c|}
\hline Indicator & Description & $\begin{array}{c}\text { Spatial } \\
\text { resolution }\end{array}$ \\
\hline \multicolumn{3}{|c|}{ Land-use indicators } \\
\hline Land coverage & $\begin{array}{l}\text { Dominant land use; } 10 \text { (urban and non-urban) land- } \\
\text { use functions }\end{array}$ & $500 * 500 \mathrm{~m}$ \\
\hline Population by urbanisation type & $\begin{array}{l}\text { Number of inhabitants in central urban, suburban, } \\
\text { peripheral regions }\end{array}$ & \\
\hline Compactness of the built-up area & $\begin{array}{l}\text { The total surface of unbroken urbanised area within a } \\
\text { certain radius for each grid cell. }\end{array}$ & $500 * 500 \mathrm{~m}$ \\
\hline \multicolumn{3}{|c|}{ Transport indicators } \\
\hline Car and public transport use & Passenger kilometres driven by mode & zone \\
\hline Travel speed & Average peak-hour car travel speed & link \\
\hline Congestion levels & $\begin{array}{l}\text { Number of km road length with peak-hour } \\
\text { intensity/capacity ratios }>0.5\end{array}$ & link \\
\hline \multicolumn{3}{|c|}{ Ecological indicators } \\
\hline $\mathrm{CO}_{2}$ emission & Total $\mathrm{CO}_{2}$ emission (tonne) of passenger transport & total NL \\
\hline $\begin{array}{l}\text { Noise nuisance from road traffic in } \\
\text { nature conservation areas }\end{array}$ & $\begin{array}{l}\text { Ratio of the surface nature area with noise emissions } \\
\text { from road traffic above/below } 40 \mathrm{~dB}(\mathrm{~A})\end{array}$ & $\begin{array}{l}500 * 500 \mathrm{~m} ; \\
\text { region }\end{array}$ \\
\hline Wildlife habitat fragmentation & $\begin{array}{l}\text { The size of connected nature areas within a certain } \\
\text { radius from each grid cell, fragmented by built-up } \\
\text { areas, the location and traffic volume of roads }\end{array}$ & $500 * 500 \mathrm{~m}$ \\
\hline \multicolumn{3}{|c|}{ Social indicators } \\
\hline $\begin{array}{l}\text { Accessibility to social and economic } \\
\text { opportunities }\end{array}$ & $\begin{array}{l}\text { Total number of population and jobs within reach by } \\
\text { car and public transport, weighted by travel time } \\
\text { away }\end{array}$ & zone \\
\hline Time spent in traffic & Total time spent in traffic by car and public transport & total \\
\hline Access to green area & Walking distance from residential to green areas & $500 * 500 \mathrm{~m}$ \\
\hline $\begin{array}{l}\text { Noise emissions from road traffic in } \\
\text { residential areas }\end{array}$ & $\begin{array}{l}\text { Total surface of residential area with noise emissions } \\
\text { from road traffic above } 55 \mathrm{~dB}(\mathrm{~A})\end{array}$ & $500 * 500 \mathrm{~m}$ \\
\hline
\end{tabular}


Table 2. Land-use and transport impacts of Liberal Urbanisation Scenarios, index for reference scenario $2000=100$

\begin{tabular}{lcc}
\hline & $\begin{array}{c}\text { Liberal } \\
\text { Urbanisation } \\
\text { Scenario }\end{array}$ & $\begin{array}{c}\text { Liberal } \\
\text { Urbanisation \& } \\
\text { Migration Scenario }\end{array}$ \\
\hline Land-use indicators & & \\
Population by urbanisation type & 89 & 83 \\
-central urban areas & 101 & 100 \\
- suburban areas & 104 & 108 \\
- peripheral areas & 70 & 90 \\
Compactness of the built-up area & & \\
Transport & 106 & 109 \\
Car use (per km) & 94 & 84 \\
Public transport use (per km) & 93 & 81 \\
Peak-hour car travel speed & 124 & 159 \\
Peak-hour congestion & & \\
\hline
\end{tabular}

Table 3. Ecological and social impacts of Liberal Urbanisation Scenarios for 2000 (index for reference scenario $2000=100$ )

\begin{tabular}{lcc}
\hline & $\begin{array}{c}\text { Liberal } \\
\text { Urbanisation } \\
\text { Scenario }\end{array}$ & $\begin{array}{c}\text { Liberal } \\
\text { Urbanisation \& } \\
\text { Migration Scenario }\end{array}$ \\
\hline Ecological impacts & 106 & 109 \\
$\mathrm{CO}_{2}$ emission from transport & 100 & 102 \\
Natural area with noise levels $>40 \mathrm{~dB}(\mathrm{~A})$ & 102 & 104 \\
Wildlife habitat fragmentation & & \\
Social impacts & & \\
Job accessibility (average day) & 93 & 102 \\
- by car & 101 & 71 \\
- by public transport & & 105 \\
Population accessibility (average day) & 94 & 104 \\
- by car & 103 & 111 \\
- by public transport & 105 & 107 \\
Access to green area within walking distance & 108 & \\
Total time spent in traffic & 105 & \\
Residential area with noise levels $>55 \mathrm{~dB}(\mathrm{~A})$ & & \\
\hline
\end{tabular}




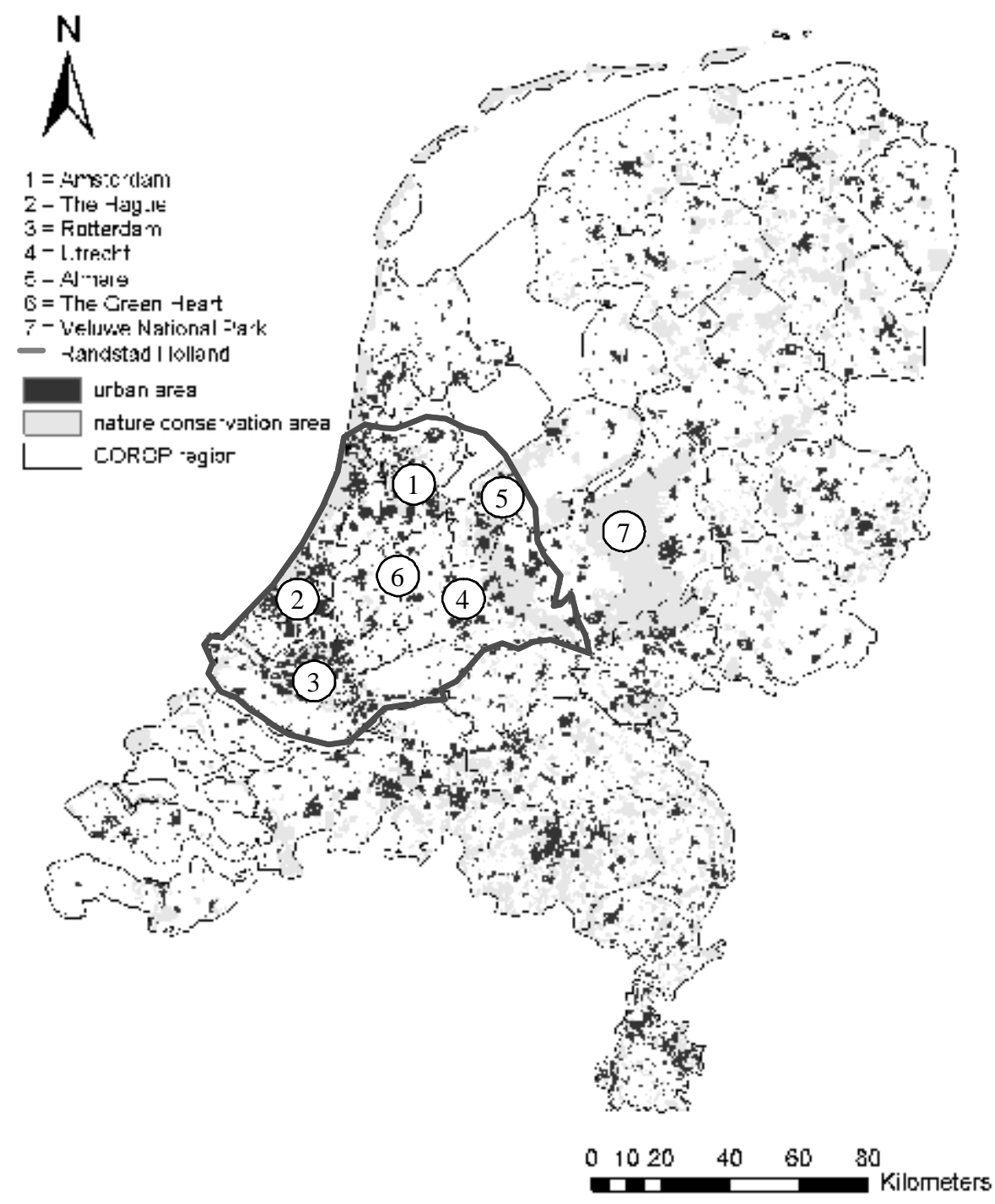

Fig. 1. Urban area and nature conservation areas in the Netherlands, 2000. 


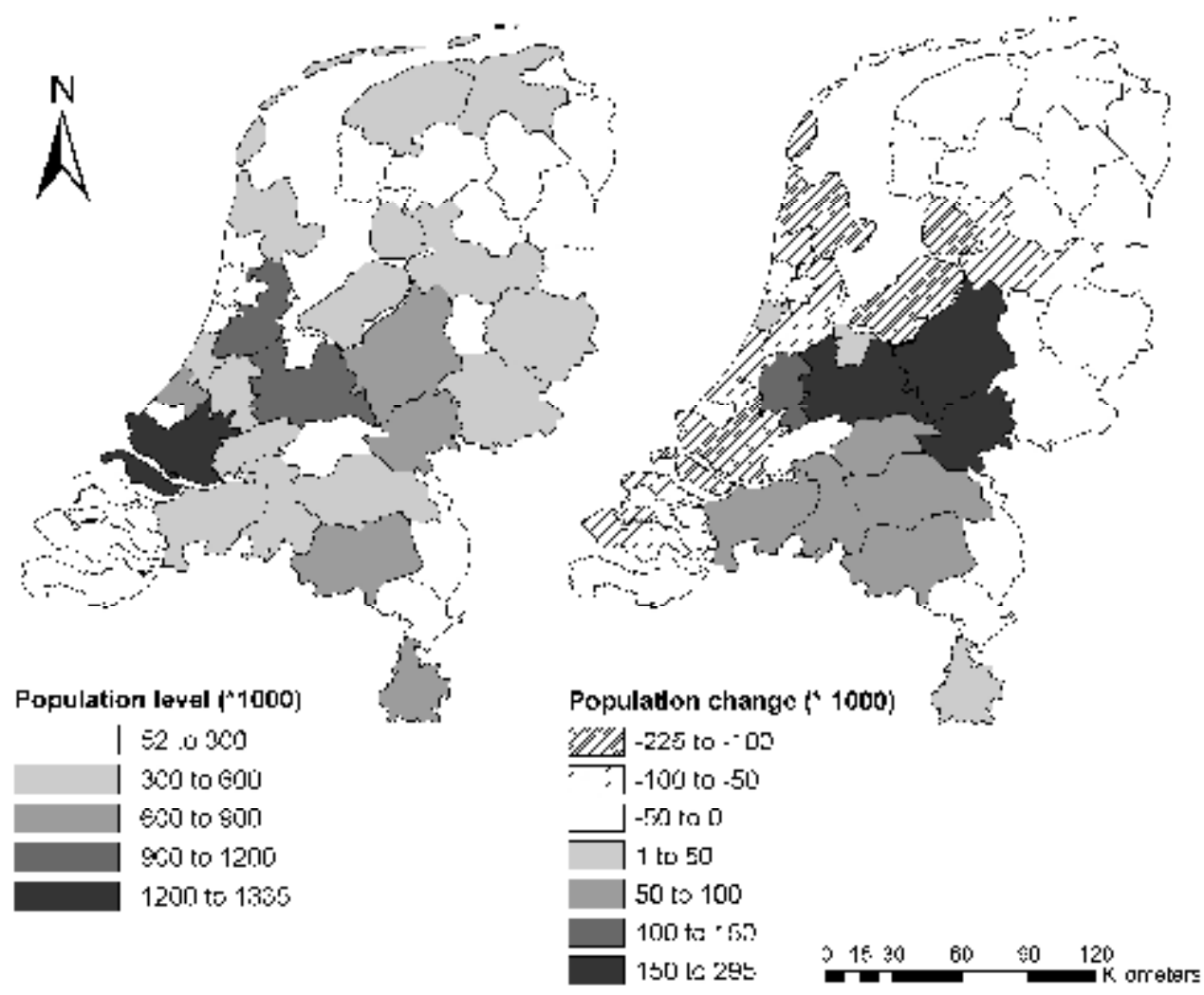

Fig. 2. Population level by COROP region in the Reference Scenario, 2000 (left) and difference in population levels between Liberal Urbanisation \& Migration Scenario and Reference Scenario, 2000 (right). 


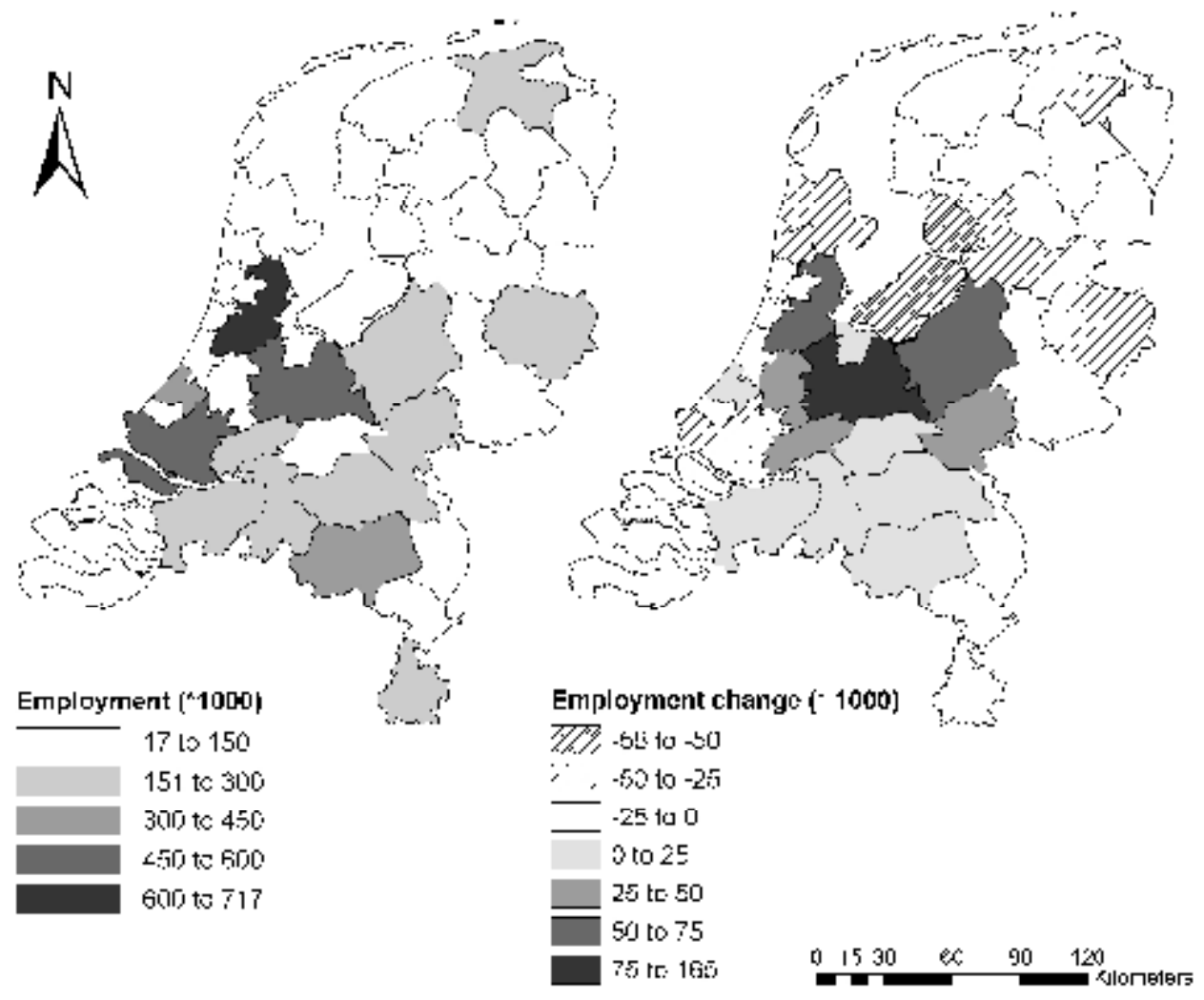

Fig. 3. Employment level by COROP region in the Reference scenario, 2000 (left) and difference in employment levels between Liberal Urbanisation \& Migration Scenario and Reference Scenario, 2000 (right). 


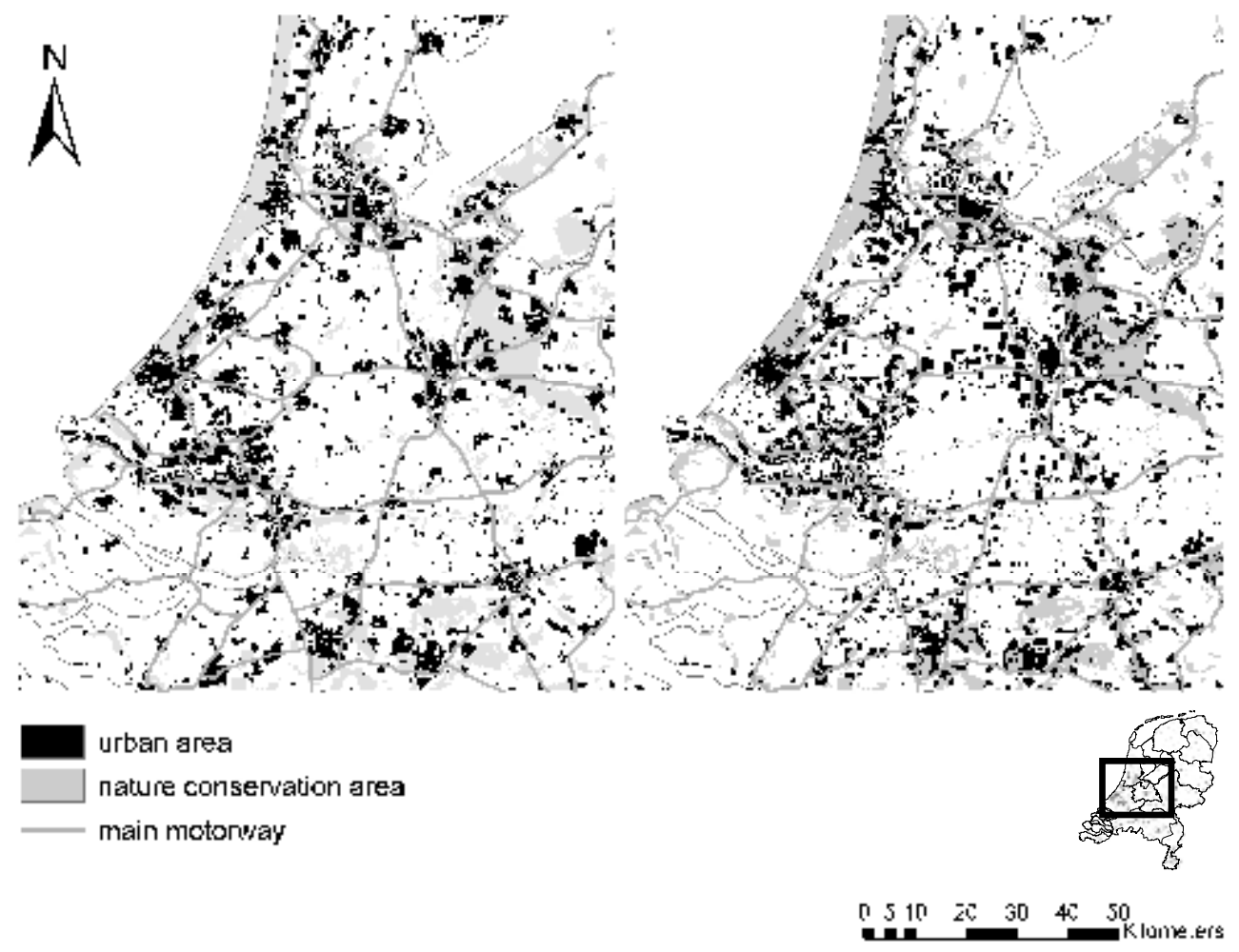

Fig. 4. Urbanisation patterns in the reference scenario (left) and the Liberal Urbanisation \& Migration Scenario (right) for the Randstad Area, 2000. 

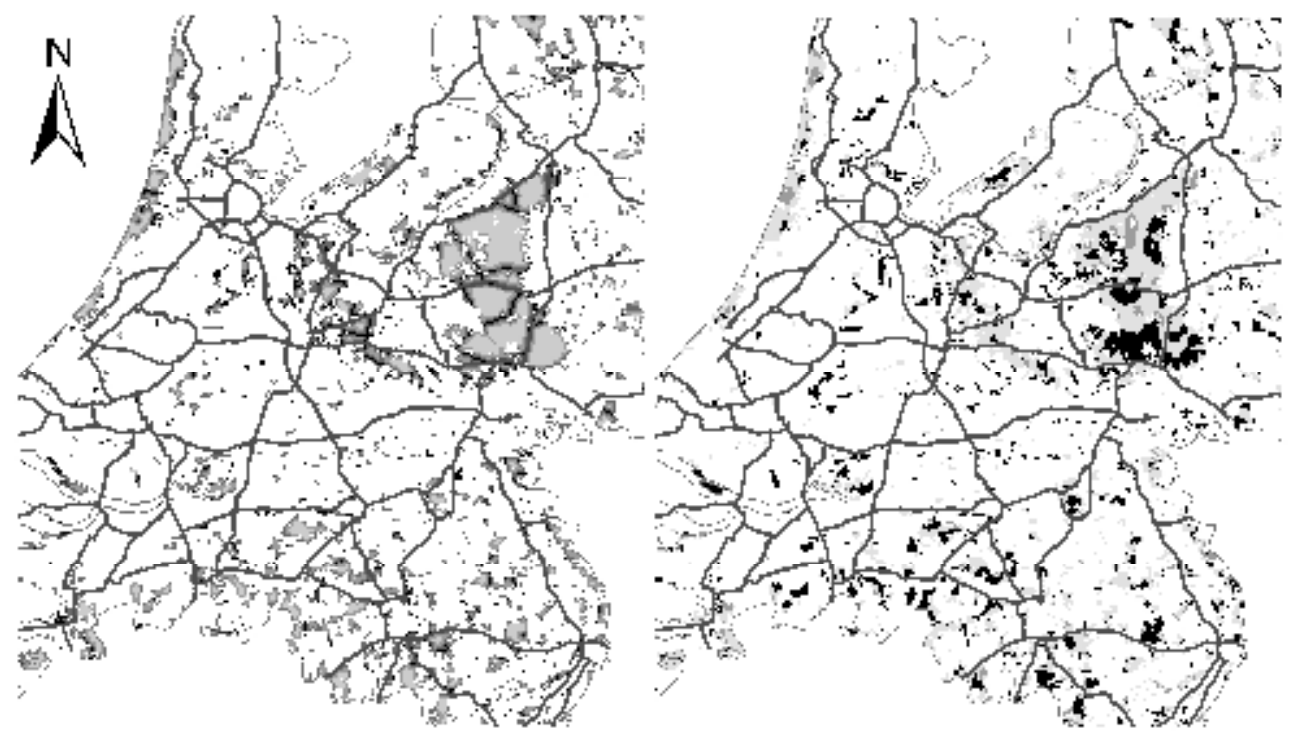

Habitat facamenta:ian

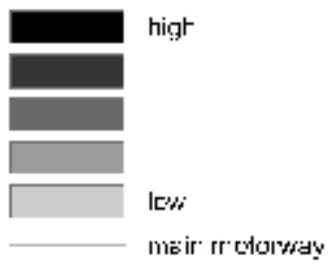

Habittat fiëgrrlents: : cri
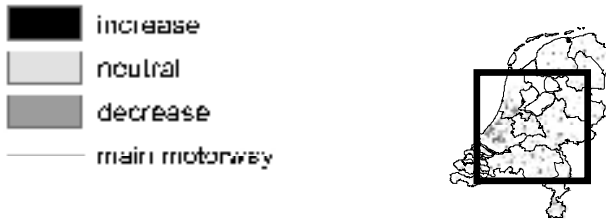

$\begin{array}{lllll}0 & 10 & 25 & 40 \quad 60 & 20\end{array}$

Fig. 5. Habitat fragmentation of nature conservation areas in the Reference Scenario, 2000 (left) and difference between the Liberal Urbanisation \& Migration Scenario and the Reference Scenario, 2000 (right). 